\title{
PRIMARY FIBROBLAST CELL CYCLE SYNCHRONIZATION AND EFFECTS ON HANDMADE CLONED (HMC) BOVINE EMBRYOS
}

\section{SINCRONIZAÇÃO DO CICLO CELULAR DE FIBROBLASTOS PRIMÁRIOS E EFEITOS NA PRODUÇÃO DE EMBRIÕES BOVINOS CLONADOS POR HANDMADE (HMC)}

\author{
Natalia Andrea Gómez ${ }^{1}$ \\ Mónica Marcela Ramírez ${ }^{2}$ \\ Zulma Tatiana Ruiz-Cortés ${ }^{1^{*}}$ \\ ${ }^{1}$ Facultad de Ciencias Agrarias, Universidad de Antioquia. Medellín, Colombia \\ ${ }^{2}$ GIBA Politecnico Jaime Isaza Cadavid, Medellín, Colombia \\ *Corresponding author: zulma.ruiz@udea.edu.co
}

\begin{abstract}
Spatial and temporal synchrony and compatibility between the receptor oocyte and the donor cell nucleus are necessary for the process of embryo cloning to allow nuclear reprogramming and early embryonic development. The objective of the present study was to evaluate three cell cycle synchronization methods on a primary bovine fibroblast culture for 24,48 , or $72 \mathrm{~h}$. These fibroblasts were used as nuclear donors to evaluate their in vitro developmental potential and the quality of the embryos produced through handmade cloning (HMC). No differences were found between the methods used for fibroblast synchronization in G0/G1 ( $p>0.05)$. Production of clones from fibroblasts in four groups- no treatment at $0 \mathrm{~h}$ and using serum restriction $\mathrm{SR}$, high culture confluence $\mathrm{HCC}$, and $\mathrm{SR}+\mathrm{HCC}$ at $24 \mathrm{~h}$ - resulted in high cleavage rates that were not different. Embryo production rates were $37.9 \%, 29.5 \%$, and $30.9 \%$ in the $0 \mathrm{~h}$, SR $24 \mathrm{~h}$, and SR+HHC24h groups, respectively, and $19.3 \%$ in the HCC group, which was significantly different from the other three (p $<0.05)$. There were no differences in the quality parameter among the clones produced with fibroblasts subjected to the different synchronization. Finally, when overall clone production was compared versus parthenotes and IVF embryos, the only difference was between clones and parthenogenetic embryos with zona pellucida (30.2\% vs 38.6\%). The number of blastomeres from the blastocytes produced through IVF was significantly greater than those from embryos activated parthenogenetically and from clones $(117,80,75.9$, and 67.1 , respectively). The evaluation of three synchronization methods at different time points did not demonstrate an increase in the percentage of fibroblasts in the G0/G1 phases of the cell cycle; however, good quality and high cloning rates were obtained, suggesting that it is not always necessary to subject the cells to any synchronization treatments, as they would yield equally good cloning results.
\end{abstract}

Keywords: cellular reprogramming; cloning organism; parthenogenesis.

\section{Resumo}

A sincronia espacial e temporal e a compatibilidade entre o oócito receptor e o núcleo celular doador são necessárias para o processo de clonagem de embriões a fim de permitir a reprogramação nuclear e o desenvolvimento embrionário precoce. O objetivo do presente estudo foi avaliar três métodos de 
sincronização do ciclo celular em uma cultura primária de fibroblastos bovinos durante 24, 48 ou 72 h. Estes fibroblastos foram utilizados como doadores nucleares para avaliar o seu potencial de desenvolvimento in vitro e a qualidade dos embriões produzidos por meio da técnica de Handmade cloning (HMC). Não foram encontradas diferenças entre os métodos utilizados para a sincronização de fibroblastos em G0 / G1 ( $\mathrm{p}>0,05)$. Produção de clones de fibroblastos nos quatro grupos - sem tratamento a $0 \mathrm{~h}$ e com restrição de soro RS, alta confluência celular ACC e RS + ACC às $24 \mathrm{~h}-$ resultou em altas taxas de clivagem que não foram diferentes. As taxas de produção de embriões foram de 37,9\%, 29,5\% e 30,9\% nos grupos 0h, RS24h e RS + ACC24h, respectivamente, e 19,3\% no grupo ACC, que foi significativamente diferente dos outros três $(\mathrm{p}<0,05)$. Não houve diferenças no parâmetro de qualidade entre os clones produzidos com fibroblastos submetidos à sincronização diferente. Finalmente, quando a produção geral de clones foi comparada versus partenotos e embriões de FIV, a única diferença foi entre clones e embriões partenogênicos com zona pelúcida $(30,2 \%$ vs 38,6\%). O número de blastômeros dos blastocitos produzidos através da FIV foi significativamente maior do que os de embriões ativados partenogeneticamente e de clones $(117,80,75,9$ e 67,1, respectivamente). A avaliação de três métodos de sincronização em diferentes pontos de tempo não demonstrou um aumento na porcentagem de fibroblastos nas fases G0/G1 do ciclo celular. No entanto, obteve-se boa qualidade e altas taxas de clonagem, sugerindo que nem sempre é necessário submeter as células a quaisquer tratamentos de sincronização, uma vez que renderiam resultados de clonagem igualmente bons.

Palavras-chave: organismo clonado; partenogênese; reprogramação celular.

Received on: August 4th, 2017.

Accepted on: December 4th, 2017.

\section{Introduction}

Cloning allows the manipulation of genetically and phenotypically superior animals, the generation of transgenic animals, and the preservation of species on the verge of extinction, It also allows the study of early embryonic development, cellular programming, and the creation of biomedical models ${ }^{(1,2)}$. Most often, researchers rely on somatic cell nuclear transfer (SCNT) for their cloning needs ${ }^{(3-5)}$. The technique is performed using micromanipulators operated by highly qualified personnel, making it costly and difficult to $\operatorname{access}^{(6)}$. As an alternative, a technique known as handmade cloning (HMC) has been developed, wherein cloning is performed using a simpler and more affordable methodology, avoiding the use of micromanipulators. This alternative technique results in birth rates comparable, and sometimes superior, to those achieved through traditional cloning. This technique can accelerate the transfer and standardization of technology and can contribute to the widespread application of cloning $^{(7,8)}$.

Nevertheless, the efficiency of this biotechnology with regards to embryo production and the birth of completely healthy animals is still low and unstable ${ }^{(6)}$, with reports of fetal and placental anomalies and miscarriage $\mathrm{e}^{(9-10)}$. These limitations have been attributed to a variety of factors, one of the most important of them is reprogramming the donor cell ${ }^{(11)}$. Until now, little had been known about the cellular and molecular events that could be involved in the genomic reprogramming of an adult somatic cell to allow it to direct embryonic and fetal development. What is clear is that there must be a coordination between the cell cycle of the donor cell and the cytoplasm of the receptor oocyte to achieve successful development post-reconstruction ${ }^{(12)}$. 
During nuclear transfer, the ideal stage of the donor cell should be G0/G1, and the receptor oocytes have not been activated yet in metaphase II (MII) ${ }^{(13)}$. The use of donor cells at other phases of the cell cycle generally leads to poor embryonic development after cloning, often due to either the pulverization of chromosomes caused by premature condensation during the $\mathrm{S}$ phase or aneuploidy during the $\mathrm{G} 2 / \mathrm{M}$ phases ${ }^{(14,15)}$.

Various methods of cell synchronization have been used as the addition of mimosine, which is an alkaloid that stops cells in late G1 phase ${ }^{(16)}$. Roscovitine is a potent aminopurine inhibitor of CDK1 / cyclin B, CDK2, and CDK5, thereby synchronizing the cells in G0 / G1. Lovastatin is a drug that arrests the cells in $\mathrm{G}^{(17)}$. These chemicals are usually toxic and, in some cell lines, they generate apoptosis. Therefore, alternatives are necessary, such as serum restriction ${ }^{(18,19)}$, which acts on the cells causing them to stop at G0 and suspend the transcription, and high cellular confluence that causes cycle inhibition by cell-to-cell contact ${ }^{(20-22)}$. These two methodologies have been used in several species with different results. For example, in cattle, Gerger et al. ${ }^{(22)}$ found the percentage of blastocysts was increased linearly when fibroblasts were used in HMC with progressive increase of cellular confluence. On the other hand, serum restriction has been effective in different experiments allowing good cycle synchronization ${ }^{(15,19)}$. However, other researchers have found its use could generate the activation of pro-apoptotic processes, which triggers DNA fragmentation and is detrimental to embryonic development ${ }^{(14)}$.

Very few studies have reported the phase of the cell cycle at which the nucleus donor cells were. So far, the doubts remain about which is the best method of synchronization of a primary culture of fibroblasts and what is the relationship between them and the embryonic development and quality after the cloning procedure. Another important aspect to be taken into account within HMC is that the oocytes are highly manipulated and subject to processes that can operate against their cellular viability. Because of these factors, it is important to use parallel processes, such as the production of parthenogenetic and in vitro-fertilized embryos to maintain control over the quality of the selected oocytes, their activation capacity, and their ability to allow for early embryonic development.

Therefore, the purpose of our study was to evaluate the efficiency of cell cycle synchronization of bovine nuclear donor fibroblasts and the capacity to produce in vitro HMC embryos reconstructed using these cells. In addition, another objective was to compare this production method with that of bovine embryos obtained by in vitro fertilization (IVF) and parthenogenesis.

\section{Materials and Methods}

A complete ear of a heifer was collected from the local slaughterhouse and transported in phosphatebuffered saline (PBS) with $20 \mathrm{mg} / \mathrm{mL}$ streptomycin and $12.53 \mathrm{mg} / \mathrm{mL}$ penicillin (SP). After washing and shaving the ear, it was cut into $\sim 3$-mm-thick pieces, which were then transferred to a 6 -well dish (4-5 explants per well) with $1 \mathrm{~mL}$ DMEM (Dulbecco's Modified Eagle Medium) culture medium supplemented with 10\% bovine fetal serum (FBS, Gibco) and SP. The explants were incubated at $38.8{ }^{\circ} \mathrm{C}$ with $5 \% \mathrm{CO}_{2}$ and $90 \%$ relative humidity until they reached $>90 \%$ confluence, which occurred approximately two weeks after cultivation (Figure 1A). The explants were removed, and the cells were detached with $0.25 \%$ trypsin and $5 \mathrm{mM}$ EDTA for 2 to $3 \mathrm{~min}$.

Cell passage was performed in a T25 culture flask, and when approximately $100 \%$ confluence was obtained, the cells were frozen with DMEM supplemented with $20 \%$ FBS and 10\% dimethyl 
sulfoxide (DMSO) in $0.25 \mathrm{~mL}$ straws, with 200,000 cells/straw for cell synchronization treatments, and 30,000 cells/straw for the HMC reconstruction process. The tubes were stored in liquid nitrogen $\left(-196^{\circ} \mathrm{C}\right)$. During cell passage and the freezing and unfreezing processes, cellular viability was determined using a $0.4 \%$ Trypan Blue solution at a 1:1 ratio, where the numbers of living (unstained) and dead (stained) cells were calculated ${ }^{(23,24)}$ (Figure 1B).

The vimentin gene expresses an intermediate filament protein characteristic of fibroblasts. To verify that the type of cells isolated and cultured corresponded to fibroblasts, DNA extraction and analysis were performed to determine if this gene was expressed ${ }^{(25)}$. Extraction was performed by centrifuging the detached cells twice with PBS to eliminate any residual culture medium that could interfere with the PCR. The pellet was then resuspended in $200 \mu \mathrm{L}$ of PBS, and total DNA extraction was performed using a DNeasy Blood and Tissue kit (QIAGEN Inc., Valencia, CA, USA) following the manufacturer's instructions. Amplification of the Bos taurus vimentin gene occurred using primers derived from the cDNA of the Bubalus bubalis vimentin gene (access number XM 006052364.1).

PCR was performed using $2.5 \mathrm{mM} \mathrm{MgCl}_{2}$, a $1 \mathrm{X}$ concentration of a $10 \mathrm{X}$ buffer with Tris- $\mathrm{HCl}$, Triton $\mathrm{X}-100$, and $\mathrm{KCl}$ (pH 8.8) (Fermentas, CA, USA), $0.15 \mathrm{mM}$ of each primer, $0.5 \mathrm{mM}$ of each dNTP, 1.5 U of Taq DNA polymerase (5 IU/ $\mu$ L, Fermentas Taq DNA Recombinant Polymerase, CA, USA), and $5 \mu \mathrm{L}$ of DNA and it was adjusted with nuclease-free water until reaching a final volume of $25 \mu \mathrm{L}$. The amplification was completed in a PTC 200 thermocycler (Perkin-Elmer Inc., San Jose, CA, USA). The conditions consisted of an initial denaturing temperature of $95{ }^{\circ} \mathrm{C}$ for $7 \mathrm{~min}$, followed by 30 cycles of denaturing at $95{ }^{\circ} \mathrm{C}$ for 30 seconds, an annealing temperature of $54{ }^{\circ} \mathrm{C}$ for $1 \mathrm{~min}$, and extension at $72{ }^{\circ} \mathrm{C}$ per min. The PCR products $(690 \mathrm{bp})$ were analyzed in a $1 \%$ agarose gel with 0.5 $\mu \mathrm{g} / \mathrm{mL}$ ethidium bromide and were detected under UV light with an imager (Model M-10E, UVP, Upland, CA, USA). The products showed bands of $690 \mathrm{bp}$, corresponding to vimentin (data not shown) according to the Gene Ruler 50 bp Ladder (Thermofisher Scientific, MA, USA).
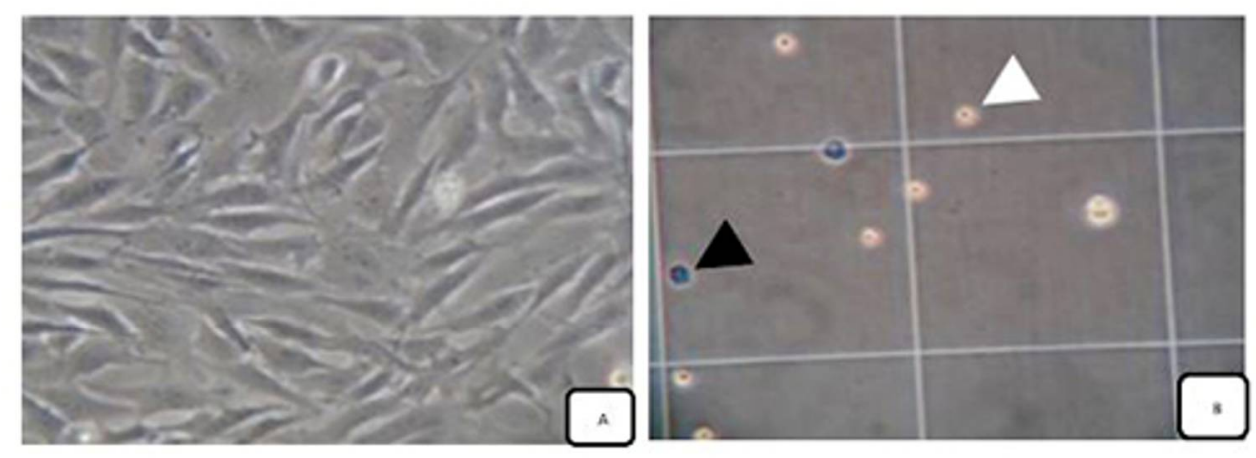

Figure 1. Fibroblast culture and evaluation of cell viability using a Trypan Blue solution.

A. Primary fibroblast culture with $100 \%$ confluence. B. Evaluation of cellular viability with Trypan Blue (white arrow indicates living cell, black arrow indicates dead cell).

Once the post-thaw culture had been established, it underwent passage in a T25 flask. When the culture reached $\sim 90-100 \%$ confluence, it was trypsinized, evaluated for cellular viability, and used to seed 10 wells with $1.5 \mathrm{~mL}$ medium at a concentration of 40,000 cells $/ \mathrm{mL}$ in 6 -well dishes. On the same day this culture was performed, a first well was also trypsinized to evaluate the cell cycle at $0 \mathrm{~h}$, as explained below. Cells were then subjected to four treatments: a) control, performed when 
evaluating at $0 \mathrm{~h}$; b) serum restriction (SR): when three of the wells reached $\sim 50-60 \%$ confluence, the medium (DMEM $+20 \% \mathrm{FBS}+10 \%$ ) was replaced by another medium containing $0.5 \% \mathrm{FSB}$. At $24 \mathrm{~h}$, one well was trypsinized to evaluate the cells for flow cytometry; this process was repeated at 48 and $72 \mathrm{~h}$; c) high culture confluence (HCC): when three of the wells reached $>95 \%$ confluence, one of them was trypsinized for cells evaluation of flow cytometry; the same process was repeated at 48 and $72 \mathrm{~h}$; d) Serum restriction+high culture confluence (SR+HCC): one cell culture was used to do simultaneously both the SR + HCC procedures; cell evaluation was performed as described in $\mathrm{b}$ and $\mathrm{c}$.

After the cells were trypsinized, they were fixed with ethanol at $90 \%$; resuspended in a solution of $50 \mu \mathrm{g} / \mathrm{mL}$ propidium iodide (Sigma) $+2 \mathrm{mg} / \mathrm{mL}$ RNase A and incubated at room temperature for $30 \mathrm{~min}$ in the dark ${ }^{(26)}$. The cells were taken to the flow cytometer and analyzed using Flow Jo software. Doublet discrimination was performed using FSC-H vs FSC-A analysis on the presumed doublet. Events with double FSC-A signal compared to FSC-H were cataloged as aggregates. Five repetitions were made in total. Since flow cytometry analysis showed a cell population with a high amount of DNA $(>4 \mathrm{C})$, thin cell layer cultures were performed on the three culture systems (SR, HCC, and SR + HCC) over the same three periods $(24,48$, and $72 \mathrm{~h})$; afterwards, they were subjected to a solution of $50 \mu \mathrm{g} / \mathrm{mL}$ propidium iodide and were evaluated using fluorescent microscopy, revealing the presence of binucleated cells (Figure 2).

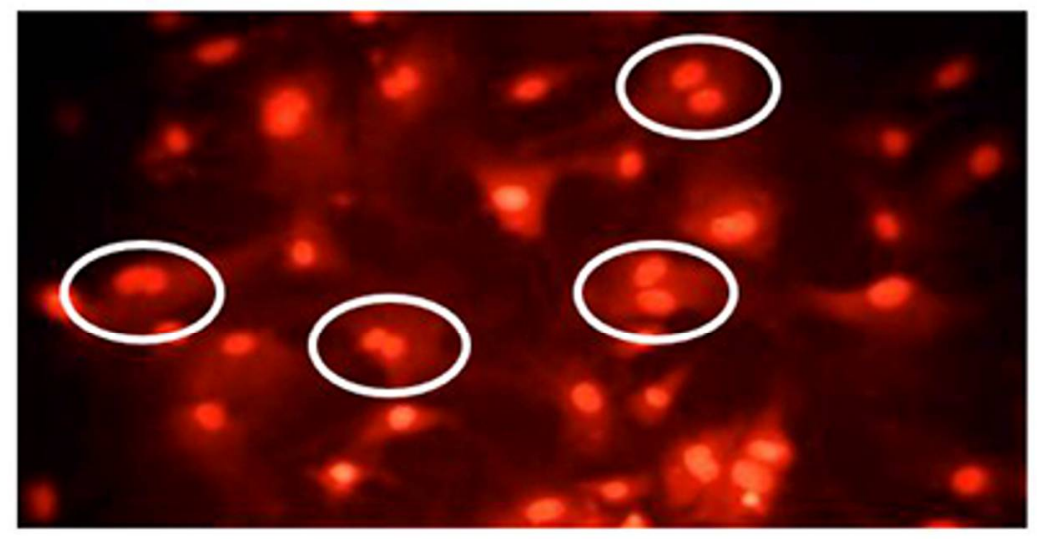

Figure 2. Thin cell layer fibroblasts culture with presence of binucleated cells (white ovals) stained with propidium iodide.

In total, 12 HMC procedures, 12 IVF procedures, and 12 parthenogenesis procedures were performed. For the in vitro maturation (IVM), oocytes were obtained from the ovaries of cows euthanized at the local slaughterhouse. The ovaries were transported in a $0.9 \%$ sterile saline solution at $30{ }^{\circ} \mathrm{C}$. Follicles between 2 and $7 \mathrm{~mm}$ in diameter were aspirated with an $18 \mathrm{G}$ needle; the follicular liquid was deposited into a $15-\mathrm{mL}$ conical tube and was allowed to decant for $20 \mathrm{~min}$. The cumulus-oocyte complexes (COCs) with homogeneous ooplasma, round morphologies, and at least three compact granulosa cell layers were selected for the IVM process ${ }^{(27)}$. Maturation was performed in $70-\mu \mathrm{L}$ drops of the maturation medium TCM-199 supplemented with $10 \% \mathrm{FBS}, 22 \mu \mathrm{g} / \mathrm{mL}$ pyruvate, $1 \mu \mathrm{g} / \mathrm{mL}$ luteinizing hormone ( $\mathrm{LH})$ and $20 \mu \mathrm{g} / \mathrm{mL}$ follicle-stimulating hormone (FSH); approximately 12 oocytes were placed into each drop, which were then incubated at $5 \% \mathrm{CO}_{2}, 38.8{ }^{\circ} \mathrm{C}$ and $90 \%$ humidity for $20 \mathrm{~h}$. After $20 \mathrm{~h}$ of IVM, cumulus expansion was evaluated visually ${ }^{(28)}$. Two groups were 
removed to initiate the parthenogenesis and cloning processes.

The remaining oocytes were fertilized by in vitro fertilization (IVF) as follows: the cryopreserved semen of a single bull from the genus $B O N$ (Colombian creole breed in Spanish Blanco Oreji-Negro) was used for all of the copies. For each process, a straw was thawed in water at $35^{\circ} \mathrm{C}$ for $1 \mathrm{~min}$. The semen was then deposited into Tyrode's albumin lactate pyruvate medium for sperm (sperm-TALP) and centrifuged to remove excess diluent used during freezing. The sample was resuspended in fertilization medium (fert-TALP) supplemented with $12 \mu \mathrm{L} / \mathrm{mL}$ heparin, $45 \mu \mathrm{L} / \mathrm{mL}$ PHE (penicillamine-hypotaurine-epinephrine), and $2.2 \mathrm{mg} / \mathrm{mL}$ pyruvate and was centrifuged again. After adjusting the final concentration to $1-2 \times 10^{6}$ spermatozoids $/ \mathrm{mL}, 10 \mu \mathrm{L}$ was deposited into each microdrop of $50-\mu \mathrm{L}$ fert-TALP medium containing the oocytes.

As for the parthenogenesis, a portion of oocytes (20-50/replication) was obtained that had polar bodies but lacked cumulus cells. The oocytes were divided into two equal groups; the first one was deposited into drops of base medium (BM: TCM199 Sigma M-2520 with $2.2 \mathrm{mg} / \mathrm{mL} \mathrm{NaHCO}_{3}$, $22 \mu \mathrm{g} / \mathrm{mL}$ pyruvate, and 10\% FBS $+1 \mathrm{X}$ Penicillin/streptomycin) for $26 \mathrm{~h}$ of maturation; the second one was placed into drops of $\mathrm{MB}+0.5 \%$ pronase-E (protease) without serum and $0.01 \%$ PVA (polyvinyl alcohol). To degrade the zona pellucida (ZP), oocytes were withdrawn from this medium when $20-30 \%$ showed thinning or deformed zona. After $26 \mathrm{~h}$ of IVM, both groups were chemically activated in drops of BM with $5 \mathrm{mM}$ ionomycin for $5 \mathrm{~min}$, then incubated in CR2 medium with $2 \%$ FBS, $0.3 \% \mathrm{BSA}$, and $2 \mathrm{mM}$ of 6-dimethylaminopurine (6-DMAP) under mineral oil for $4 \mathrm{~h}$ and cultured in vitro. The parthenotes lacking zona pellucida were cultivated using the WOW (well of well) system. To do so a dish was prepared with four wells containing $400 \mu \mathrm{L}$ of CR2 medium and $200 \mu \mathrm{L}$ of mineral oil each, followed by making small indentations at the bottom of each well to create microwells. Parthenotes with zona pellucida were cultured in a well with CR2 medium.

To obtain cytoplasts, $20 \mathrm{~h}$ post-IVM, COCs were denuded using smooth pipetting; those that had expelled the first polar body (PB) were selected and washed in various BM drops. The COCs were incubated for $1 \mathrm{~h}$ in drops of $\mathrm{BM}+10 \mu \mathrm{g} / \mathrm{mL}$ demecolcine for nuclear ejection. The $\mathrm{ZP}$ was removed, exposing the oocytes to $0.5 \%$ pronase in $\mathrm{BM}$ without serum $+0.01 \%$ PVA for approximately 30 seconds. A total of 1 to 2 oocytes lacking ZP were placed into microdrops of $5 \mu \mathrm{L} \mathrm{BM}+5 \mathrm{mg} / \mathrm{mL}$ cytochalasin B (CCB) covered in mineral oil (60-80 drops/dish). The oocytes were dissected based on visualization of the ejection to complete nucleus removal. The resulting cytoplasm obtained was the cytoplast to be used during HMC. Dissection was performed with an Ultra Splitting Sharp knife (Bioniche).

For the embryonic reconstruction, a 100-mm Petri dish was prepared with 4-5 drops of BM, 3 drops of BM without serum $+500 \mu \mathrm{g} / \mathrm{mL}$ PHA (phytohemagglutinin). Approximately 10 cytoplasts were deposited into one drop of BM, while another drop received the fibroblast suspension previously subjected to $0.25 \%$ trypsin and washed with BM medium. Cytoplasts (4-6 total) were transferred to a drop of PHA; 2-3 of these cytoplasts were then passed to the drop of cellular suspension. Each cytoplast was carefully rolled close to a single round cell (fibroblast) with a sealed capillary tube until they joined together. The cytoplast-cell duos were returned to the PHA drop and pushed toward another single cytoplast until they joined, forming a trio (cytoplast-cell-cytoplast).

Regarding the electrofusion and activation, each trio was firstly oriented horizontally by means of a BLS fusion chamber model GSS-250 (250 $\mu \mathrm{m}$ interelectrode distance) covered in ME medium 
(fusion medium). Then the trio was subjected to two $25-\mathrm{V}, 20-\mu$ s square wave pulses, using a BLS CF-150B electrical impulse generator, to perform membrane fusion. The potential zygotes were withdrawn from the chamber, washed in BM drops, and individually incubated in $\sim 5 \mu \mathrm{L}$ of BM under mineral oil for 30 to $45 \mathrm{~min}$. The fusion rate was evaluated visually, verifying the formation of a single structure. The cells were chemically activated within 26-30 h after the start of IVM using the same methods for the parthenogenesis procedure described previously. After activation, the potential zygotes were washed a number of times in culture medium CR2 $+33 \mu \mathrm{g} / \mathrm{mL}$ pyruvate $+5 \% \mathrm{FBS}+$ $50 \mathrm{mg} / \mathrm{mL}$ BSA and were cultured with the WOW system, being one embryo deposited into each microwell and cultured at $38.8{ }^{\circ} \mathrm{C}$, with $5 \% \mathrm{CO}_{2}$ and $90 \%$ relative humidity for 7 days. At $72 \mathrm{~h}$ in culture, the cellular division rate (cleavage) was visually evaluated, taking note of those zygotes with at least two cells.

On day 7, the embryo production rate was evaluated for clones, parthenotes with and without zona pellucida, and embryos from IVF, taking into account the different stages of development from the morula to the expanded blastocyst (Figure 3, A, B, and C). The development stages and embryo morphological quality were evaluated according to the guidelines of the International Embryo Transfer Society ${ }^{(29)}$. To determine the number of blastomeres, embryos obtained in all groups were fixed in $70 \%$ alcohol and stained with $10 \mu \mathrm{g} / \mathrm{mL}$ Hoechst for $5 \mathrm{~min}$. Counting was performed under a Zeiss fluorescence microscope; to minimize reading errors, two observers performed the procedure twice each, and the values were averaged to assign the number of blastomeres to each embryo (Figure 3, D, E, and F). Unless otherwise specified, all reagents were from SIGMA Aldrich, St. Louis, MO, USA.
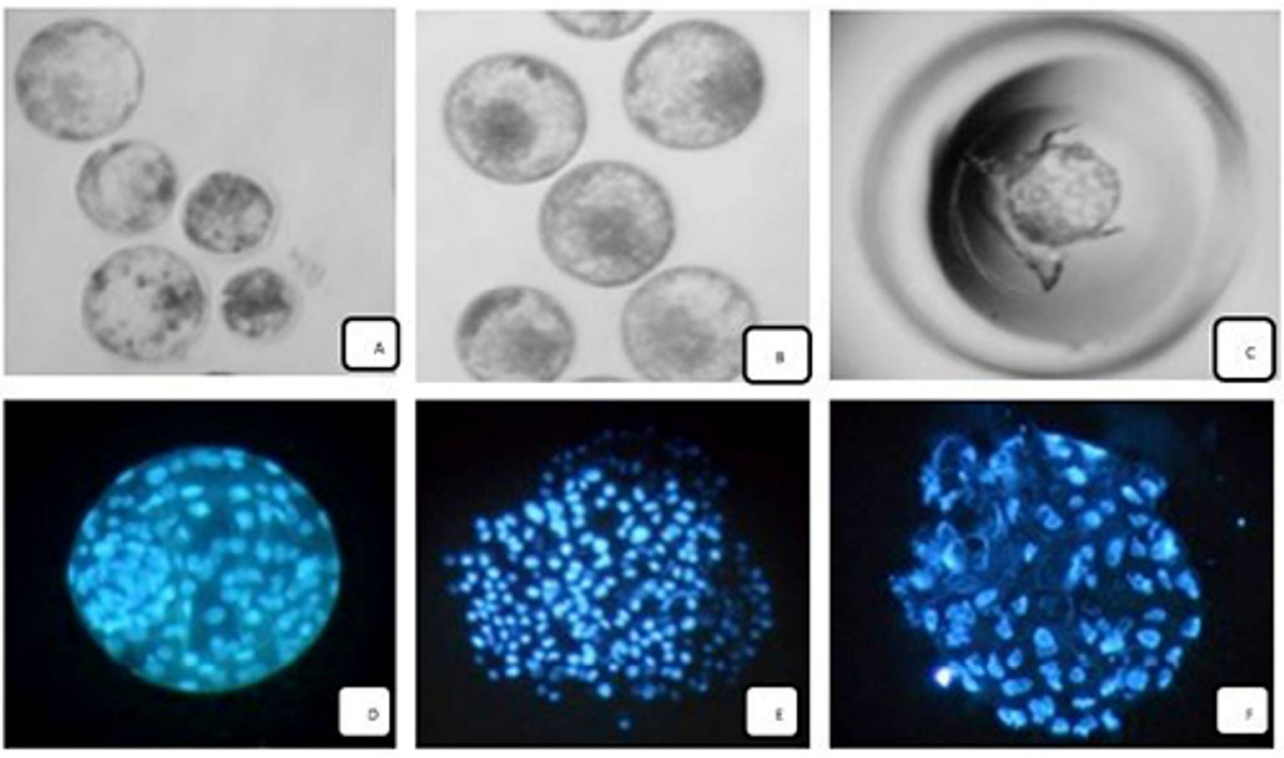

Figure 3. Embryo production and evaluation of the number of cells via fluorescent Hoechst staining. A. Parthenogenetic embryos with ZP. B. Embryos produced via IVF. C. Clone produced through HMC. D. Parthenogenetic embryo with ZP; E. IVF embryo; and F. Clone.

Shapiro-Wilk and Levene's tests were performed to test the null hypotheses of normality of data 
distribution and of homogeneity of variance, respectively; one-way ANOVA was then performed to determine differences among the average percentages of fibroblasts in the G0/G1 phases, cleavage, number of embryos and number of blastomeres among the clones, parthenotes, and IVF embryos. Data were analyzed using IBM SPSS Statistics software version 22.0, Armonk, New York United States.

\section{Results}

Flow cytometry data revealed the following populations: low, medium and high. Low populations are those with low DNA content (hypodiploids, low); high populations are those that, while conserving linearity, emitted signals with peaks higher than $4 \mathrm{C}$, characteristic of endoreplication and verified using fluorescent microscopy with propidium iodide staining (Figure 2). Excluding these endoreplicant and hypohaploid regions, the only populations considered were in the medium group, those which had 2C and 4C peaks and which were fit to the cell cycle model (Graph 1). Comparison of the percentages of cells in the G0/G1 phase across treatments and times $(0 \mathrm{~h}, \mathrm{SR} 24 \mathrm{~h}, \mathrm{SR} 48 \mathrm{~h}$, SR72h，HCC24h，HCC48h，HCC72h，SR+HCC24h，SR+HCC48h，SR+HCC72h) showed no statistically significant differences $(p>0.05)$ (Table 1) across treatments and culture durations. However, the initial group $(0 \mathrm{~h})$ showed the greatest number of cells at this phase (Graph 1$)$.

Table 1. Percentages of fibroblasts at different phases of the cell cycle subjected to three different culture methods: $\mathrm{SR}$ - serum restriction, $\mathrm{HCC}-$ high cell confluence, $\mathrm{SR}+\mathrm{HC}-$ combination of both methods

\begin{tabular}{ccccc}
\hline $\begin{array}{c}\text { Cell cycle phase } \\
(\%)\end{array}$ & $\begin{array}{c}\text { Time } \\
\text { G2/M }\end{array}$ & G0/G1 & \multicolumn{2}{c}{ S } \\
\hline START & 0 & 50.47 & 18.62 & 30.90 \\
\hline SR & 24 & 30.25 & 8.74 & 61.02 \\
& 48 & 31.53 & 12.63 & 55.83 \\
& 72 & 41.93 & 16.75 & 41.32 \\
\hline HCC & 24 & 26.02 & 26.99 & 46.99 \\
& 48 & 33.10 & 23.55 & 43.33 \\
& 72 & 28.69 & 34.04 & 37.26 \\
\hline SR+HCC & 24 & 34.49 & 19.57 & 45.94 \\
& 48 & 41.01 & 19.26 & 39.73 \\
& 72 & 40.37 & 13.66 & 45.98 \\
\hline
\end{tabular}



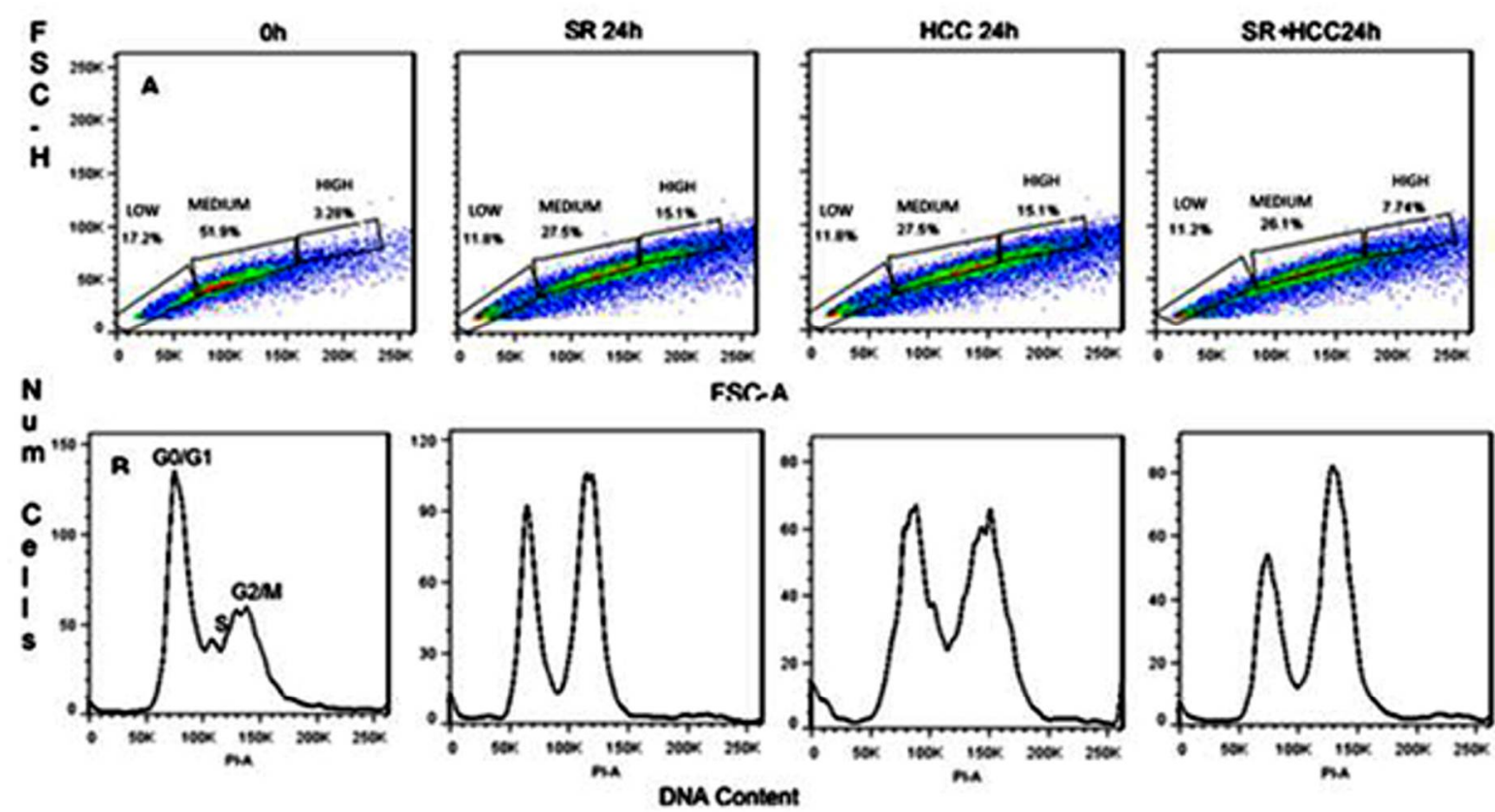

Graph 1. Flow cytometry results after three synchronization methods (SR-serum restriction, HCC-high cell confluence, $\mathrm{SR}+\mathrm{HC}$ ) of fibroblast cells during $24 \mathrm{~h}$. A. Distribution of low, medium, and high cell populations, grouped by culture method. B. Histograms of cell cycles, grouped by culture method.

As there was no statistically significant difference in the percentages of cells in the G0/G1 phase among the different treatments, clone production was performed with fibroblasts from the $0 \mathrm{~h}, \mathrm{SR} 24 \mathrm{~h}$, HCC24h, and SR+HCC24h groups. The cleavage and clone percentages are shown in Table 2.

Table 2. Clone production as a function of the nuclear donor fibroblast synchronization method

\begin{tabular}{cccc}
$\begin{array}{c}\text { Synchronization } \\
\text { method and time } \\
\text { (h) }\end{array}$ & $\begin{array}{c}\text { \% cleavage in the } \\
\text { cloned embryos }\end{array}$ & $\begin{array}{c}\text { \% production of } \\
\text { cloned embryos }\end{array}$ & P \\
\hline 0 & $80.3^{\mathrm{a}}$ & $37.9^{\mathrm{a}}$ & 0.575 \\
\hline SR 24 & $66.5^{\mathrm{a}}$ & $29.5^{\mathrm{a}}$ & 0.363 \\
\hline HCC 24 & $75.6^{\mathrm{a}}$ & $19.3^{\mathrm{b}}$ & 0.024 \\
\hline SR+HCC 24 & $60.1^{\mathrm{a}}$ & $30.9^{\mathrm{a}}$ & 0.264 \\
\hline
\end{tabular}

Different letters within a column indicate statistically significant differences $(\mathrm{p}<0.05)$.

The clones obtained from nuclear donor fibroblasts subjected to different cell cycle synchronization treatments were processed to determine the total number of blastomeres; the average number of cells per clone in each group is shown in Table 3 . There were no statistically significant differences among the groups. 
Table 3. Embryonic quality of clones as a function of the number of cells, produced using fibroblasts subject to different cell synchronization treatments

\begin{tabular}{cc}
\hline $\begin{array}{c}\text { Synchronization method and time } \\
\text { (h) }\end{array}$ & Number of blastomeres \\
\hline 0 & $68.15 \pm 9.8^{\mathrm{a}}$ \\
\hline SR 24 & $62.33 \pm 12.7^{\mathrm{a}}$ \\
\hline HCC 24 & $79.91 \pm 12.7^{\mathrm{a}}$ \\
\hline SR+HCC 24 & $61.31 \pm 11.06^{\mathrm{a}}$ \\
\hline
\end{tabular}

Different letters within a column indicate significant differences $(\mathrm{p}<0.05)$.

Evaluation of early development in clones with parthenogenetic embryos with and without zona pellucida and those obtained through IVF found no significant differences in cleavage percentage among the three groups (Clones, PWZP+PWoZP, and IVF). A statistically significant difference was found in percentage of embryo production between the clone group and the group of parthenotes with zona pellucida $(\mathrm{p}=0.036)$ (Table 4$)$.

The total numbers of cells (blastomeres) were compared across parthenogenetic embryos with and without zona pellucida, cloned embryos, and embryos created through IVF. There was a statistically significant difference in the number of cells in the IVF embryos compared to the parthenogenetic and cloned embryos $(\mathrm{p}<0.01)$ (Table 4$)$.

Table 4. Embryonic development of bovine clones, parthenotes with zona pellucida (PWZP), parthenotes without zona pellucida (PWoZP), and embryos fertilized in vitro (IVF), and the total number of blastomeres that comprise an embryo

\begin{tabular}{lccc}
\hline \multicolumn{1}{c}{ Group } & Cleavage (\%) & $\begin{array}{c}\text { Embryonic } \\
\text { production (\%) }\end{array}$ & $\begin{array}{c}\text { Total number of } \\
\text { cells }\end{array}$ \\
\hline Clones & $69.2 \pm 3.4^{\mathrm{a}}$ & $30.2 \pm 2.1^{\mathrm{d} . b . \mathrm{c}}$ & $67.1 \pm 6.9^{\mathrm{a}}$ \\
\hline PWZP & $74.2^{\mathrm{a}} \pm 3.3^{\mathrm{a}}$ & $38.6 \pm 2.1^{\mathrm{a}}$ & $80.0 \pm 4.8^{\mathrm{a}}$ \\
\hline PWoZP & $81.3 \pm 3.3^{\mathrm{a}}$ & $35.0 \pm 2.1^{\mathrm{a} . \mathrm{b}}$ & $75.9 \pm 5.2^{\mathrm{a}}$ \\
\hline IVF & $73.9 \pm 3.7^{\mathrm{a}}$ & $33.3 \pm 2.3^{\mathrm{a} \cdot \mathrm{b} \cdot \mathrm{c}}$ & $117.0 \pm 5.0^{\mathrm{b}}$ \\
\hline
\end{tabular}

Different letters within a column indicate significant differences $(\mathrm{p}<0.05)$.

\section{Discussion}

During the cloning process, the type, origin, and initial conditions of the nuclear donor cell are primary contributing factors toward the success of the technique. Spatial and temporal synchrony and compatibility between the cytoplasm of the receptor oocyte and the nucleus of the donor cell are necessary so that nuclear reprogramming and early embryonic development can begin and finish properly ${ }^{(12,30)}$. A number of protocols have been proposed to achieve this synchronization, including the use of drugs that directly or indirectly halt the cell cycle, such as roscovitine ${ }^{(31)}, \mathrm{DMSO}^{(32)}$, or cycloheximide $^{(33)}$. While effective, these agents appear to interfere with other cellular processes as a result of potentially toxic effects that could induce cell death ${ }^{(34)}$ and can cause other unexpected consequences for later cell development ${ }^{(31)}$. Because of these possibilities, methodologies free of chemical agents have been suggested that only require manipulation of culture conditions, such as 
$\mathrm{SR}^{(18,19)}$, which acts on the cells by suspending transcription, or HCC, which causes cycle inhibition via contact ${ }^{(20-22)}$. Both methods pause the cells in the $\mathrm{G} 0 / \mathrm{G} 1$ phases, both considered the most appropriate for adequate genome reprogramming, doubtless due to differences in the DNA content of the donor nuclei, which varies as a function of the phase of the cell cycle $15,35,36)$.

The three synchronization methods examined in this study were SR, HCC, and a combination of both types, each at three different times $(24,48$, and $72 \mathrm{~h})$. There were no significant differences found among the treatments, similar to the study by Hayes et al. ${ }^{(37)}$, who found no difference in the percentage of cells in $\mathrm{G} 0 / \mathrm{G} 1$ regardless of the origin or type of cell (bovine granulosa and fibroblasts) after HCC or SR culture. However, differing from our study, that group did find greater numbers of cells in the G0/G1 phases. High percentages of cells in these phases have also been reported by various authors, such as Boquest et al. ${ }^{(21)}$, who evaluated medium and high confluence in fetal porcine fibroblasts and found $74.1 \%$ and $85 \%$ of cells in the G0/G1 phases, respectively. Similarly, Sun et al. ${ }^{(38)}$ demonstrated an elevated proportion of transgenic bovine fibroblast cells in G0/G1 (91.4\%) in cell cultures with HCC. Sadeghian-Nodoushan et al. ${ }^{(16)}$ evaluated HCC at one time-point and SR at 24,48 , and $72 \mathrm{~h}$ in a culture of sheep granulosa cells and found high percentages of cells in G0/G1 (73.1, 76.9, 83.5, and 89.4\%, respectively), but no significant differences between the HCC and SR treatments; the percentage of cells in G0/G1 in the control group (56.4\%) was similar to the initial state of cells in the present study $(50.4 \%, 0 \mathrm{~h})$.

Generally, the HCC group had a low number of cells in the G0/G1 phase and a higher number in the $\mathrm{S}$ (synthesis) phase; incidentally, this phase is least indicated for the cloning process, as it tends to produce premature chromosome condensation, resulting in partial DNA "destruction" (14). Similarly, all groups and times showed high percentages of cells in the G2/M phases, which cause problems with the chromosome number (aneuploidy) that are deleterious for embryonic development ${ }^{(15)}$. In the present study, the initial state of culture produced the greatest number of cells in the G0/G1 phase, which could indicate that it is not necessary to apply synchronization methodologies at all. Nevertheless, studies on cell cultures emphasize the necessity to first acquire information on subpopulations, intending to separate those of interest to obtain cultures with homogeneous populations and thus obtain synchronizations with minimal disturbances ${ }^{(39,40)}$.

It is important to mention that the flow cytometry analysis produced three different cell populations. One had low DNA content $(<2 \mathrm{C})$ and was probably composed of hypodiploids, which, upon undergoing cell death, lose chromosomes. Another population consisted of cells with DNA between $2 \mathrm{C}$ and $4 \mathrm{C}$; this group was analyzed for cell cycle synchronization. Finally, the third population had cells with high DNA content $(>4 \mathrm{C})$; preliminary characterization of this group was performed on a thin cell layer culture using propidium iodide staining, resulting in the detection of binucleated cells (Figure 2). These cells could be the result of endoreplication, a result of failure in cytokinesis or cell fusion; the presence of binucleated cells suggests the possibility that during cycle analysis, there was an overestimation of the number of cells in the G2/M phases. Although flow cytometry alone cannot determine the exact phenomenon that resulted in binucleation, time and stressful conditions in cellular cultures increase the possibility of the presentation of mutation phenomena in DNA and of epigenetic alterations, such as histone phosphorylation ${ }^{(41)}$. These phenomena could result in high aneuploidy rates, due possibly to the reduced capacity to proliferate and migrate and in susceptibility to senescence via cell cycle inhibition or via delays in its progression ${ }^{(42)}$. The presence of this phenomenon in this study indicates the need for future studies to perform separation and characterization of subpopulations within primary cultures (as mentioned earlier) to determine the true effects of the type of culture on cell cycles, potential synchronization, and its further use during cloning. 
It was decided to perform the HMC process with cells at the initial state $(0 \mathrm{~h})$ and the simplest fibroblast cultures at the methodology level (SR, HCC, and SR+HCC at $24 \mathrm{~h}$ ) after not detecting differences among the cell synchronization treatments. The cleavage percentages obtained in this study are optimal, not significantly different among the four groups, and are within levels reported by other authors ${ }^{(19-22)}$. High percentages of embryo production were obtained in the $0 \mathrm{~h}, \mathrm{SR} 24 \mathrm{~h}$, and SR+HCC24h groups $(37.9 \%, 29.5 \%$, and $30.9 \%$, respectively) but not in the HCC24h group (19.3\%), which was significantly different from the rest. This specific group showed a large number of fibroblasts in the S phase, which could explain the relatively low number of embryos produced. In contrast, the initial group $(0 \mathrm{~h})$ showed the highest percentage of embryos $(37.9 \%)$, significant in that this group also showed the highest number of cells in the G0/G1 phases $(50.47 \%)$. This finding is agrees with the results of other studies, where a greater number of nuclear donor cells found in the G0/G1 phase was correlated with higher percentages of embryonic production ${ }^{(22)}$. The authors reported blastocyst rates that increased linearly (7.0, 17.5, and 29.4\%) with increased cellular confluence (70-80, 80-90, and >95\%).

Upon comparing the number of cells or blastomeres as a measure of embryo quality ${ }^{(43)}$, the clone group showed a good number of cells but was not significantly different compared to the other groups $(p>0.05)$. This finding might suggest that the type of culture from which nuclear donor cells originate does not affect embryonic quality.

During HMC, oocytes are highly manipulated and subjected to processes that could be detrimental to their cellular viability. Consequently, parallel processes were employed, such as the production of parthenogenetic and IVF embryos, to control the quality of the selected embryos, their capacity to chemically activate, and the ability to allow early embryonic development ${ }^{(44)}$. Thus, three control groups to the HMC technique were included: (1) parthenotes with ZP; (2) parthenotes without ZP; and (3) embryos produced through IVF. Embryo production via HMC, parthenogenesis, and IVF was compared, evaluating cleavage, percentage of embryos, and number of blastomeres. No statistically significant differences were found among any of the techniques. The percentage of embryos was different between the clone group and the parthenogenetic embryos with zona pellucida, but, in general, the cleavage and embryonic production percentages were high and similar to those obtained in other studies ${ }^{(22,45)}$.

The number of blastomeres in the blastocysts produced through IVF was significantly greater than those produced through parthenogenesis and cloning (117.0 vs 80.0 vs 75.9 vs 67.1); these observations are similar to and exceed the results of other studies in both IVF embryos and cloned bovine embryos ${ }^{(46,47)}$. This finding would indicate that the production system used is efficient in both blastocyst production and embryonic quality.

Another important result of this study is the total percentage of cloned bovine embryo production, which, compared with other studies, exceeds the percentage of blastocyst production $(30.2 \%$ vs $19 \%)^{(48)}$ and difference from the group of embryos fertilized in vitro, which is within commercial levels $(30 \text { to } 35 \%)^{(49)}$, is not statistically significant.

Today, doubts persist about which synchronization method is better for fibroblast cultures and about the nature of the relationships between the methods and embryonic development and quality after cloning. The methodologies examined in this study show a wide variation in cell cycle synchronization time and are somewhat unpredictable. Additionally, deeper understanding about the cell line or the type of donor cell used and of the number of optimal passages is required. The culture conditions could induce positive or negative changes in cell growth patterns in culture, potentially 
leading to suboptimal populations for cloning ${ }^{(50)}$; this possibility is noted in the results of this study, which indicate that it is better not to intervene in the cell cycle to achieve synchronization.

\section{Conclusions}

The evaluation of three synchronization methods (SR, HCC, and SR+HCC) at different time points did not demonstrate an increase in the percentage of fibroblasts in the G0/G1 phases of the cell cycle. However, despite this finding, good quality, high cloning rates were obtained, suggesting that depending on the origin of the cell, the cell type, and its culture base, on occasion, it would be better not to subject the cells to any synchronization treatments, as they would still yield equally good, or even better, cloning results.

Few studies on HMC report on which phase of the cell cycle was used to obtain nuclear donor cells. It is necessary to improve the cell selection technique via cytometry to know exactly what type of nuclear donor cell is used for the cloning process, thus enabling a more accurate evaluation of the true effects on the resulting clones.

The potential applications of cloning using somatic cells are still in their infancy, due to the low efficiency of the techniques used to obtain cloned embryos and the diverse problems these techniques have regarding embryonic, fetal, and neonatal development. Because of these considerations, it is vastly important that further research focus on explaining and understanding the numerous variables involved in the cloning process, be it via SCNT or HMC, to be able to manipulate the cells and to establish procedures that can increase the percentages of successful embryos above the levels obtained nowadays.

A greater understanding of the compatibility between the cell cycles of the receptor cytoplasm and the nucleus of the donor cell would allow for improving the cloning process, resulting in an increase in cloning efficiency.

\section{Acknowledgements}

To the Cytometry Unit of SIU at the University of Antioquia. To the research group in Cellular and Molecular Biology at the University of Fortaleza, Brazil. To the University of Antioquia for its support.

\section{References}

1. Niemann H, Kues W, Adrea L, Joseph W. Somatic Cloning and epigenetic reprogramming in mammals. In: Atala A, Lanza R, Thomson JA, Nerem RM (eds.), Principles of Regenerative Medicine, 1st ed. Burlington: Academic Press, 2008 148-167. DOI:10.1016/B978-0-12-381422-7.1000-7-0.

2. Shi J, Rong Z, Lvhua L, Ranbiao M, Haiyu Z, Xiaoyan H, et al. Influence of embryo handling and transfer method on pig cloning efficiency. J Anim Reprod Sci. 2015; 154,121-127. DOI: 10.1016/j.anireprosci.2015.01.006.

3. Vajta G. Handmade cloning: the future way of nuclear transfer?. Trends Biotecn. 2007; 25, 250-253. DOI: 
10.1016/j.tibtech.2007.04.004.

4. Whitworth RS, Prather KM. Somatic cell nuclear transfer efficiency: How can it be improved through nuclear remodeling and reprogramming? J Mol Reprod Develop. 2010; 77, 1001-1015. DOI: $10.1002 / \mathrm{mrd} .21242$.

5. Zhao J, Whyte J, Prather RS. Effect of epigenetic regulation during swine embryogenesis and on cloning by nuclear transfer. J Cell Tissue Res. 2010b; 341, 13-21. DOI: 10.1007/s00441-010-1000-x.

6. Vajta G, Gjerris M. Science and technology of farm animal cloning: state of the art. J Anim Reprod Sci. 2006; 92,211-230. DOI: 10.1016/j.anireprosci.2005.12.001.

7. Vajta G, Lewis IM, Hyttel P, Thouas GA, Trounson AO. Somatic cell cloning without micromanipulators. Cloning. 2001; 3, 89-95. DOI: 10.1089/15204550152475590.

8. Mizutani E, Sayaka W, Teruhiko W. Treatment of Donor Cell/Embryo with Different Approaches to Improve Development after Nuclear Transfer. J Meth Mol Biol. 2015; 1222, 101-111. DOI: 10.1007/978-14939-1594-1_8.

9. Farin PW, Piedrahita JA, Farin CE. Errors in development of fetuses and placentas from in vitro-produced bovine embryos. Theriogenology. 2006; 65,178-191. DOI: 10.1016/j.theriogenology.2005.09.022.

10. Bertolini M, Bertolini LR, Gerger RP, Batcherler CA, Anderson GB. Developmental problems during pregnancy after in vitro embryo manipulations. Rev Bra Reprod Anim. 2007; 31,391-405.

http://www.cbra.org.br/portal/publicacoes/rbra/2007/rbrajs2007.html.

11. Kumar BM, Maeng GH, Lee YM, Lee JH, Jeon BG, Ock SA, et al. Epigenetic modification of fetal fibroblasts improves developmental competency and gene expression in porcine cloned embryos. J Vet Res Commun. 2013; 37, 19-28. DOI: 10.1007/s11259-012-9542-x.

12. Wells DN, Forsyth JT, McMillan V, Oback B. Review: The Health of Somatic Cell Cloned Cattle and Their Offspring. Cloning Stem Cells. 2004; 6, 101-110. DOI: 10.1089/1536230041372300.

13. Ideta A, Hayama K, Urakawa M, Tsuchiya K, Aoyagi Y, Saeki K. Comparison of early development in utero of cloned fetuses derived from bovine fetal fibroblasts at the G1 and G0/G1 phases. J Anim Reprod Sci. 2010; 119,191-197. DOI: 10.1016/j.anireprosci.2010.02.006.

14. Collas P, Sullivan EJ, Barnes FL. Histone H1 kinase activity in bovine oocytes following calcium stimulation. J Mol Reprod Develop. 1993; 34,224-231. DOI: 10.1002/mrd.1080340215.

15. Campbell KH, McWhir J, Ritchie WA, Wilmut I. Sheep cloned by nuclear transfer from a cultured cell line. Nature. 1996; 380, 64-66. DOI: 10.1038/380064a0.

16. Sadeghian-Nodoushan F, Eftekhari-Yazdi P, Dalman A, Eimani H, Sepehri H. Mimosine As Well As Serum Starvation Can Be Used for Cell Cycle Synchronization of Sheep Granulosa Cells. Chinese J Biol. 2014; http://dx.doi.org/10.1155/2014/851736.

17. Davis PK, Ho A, Steven F. Biological Methods for Cell-Cycle Synchronization of Mammalian Cells 
BioTechniques. Rev BioTech. 2001; 30, 1322-1331. PMID: 11414226.

18. Wilmut I, Schnieke AE, McWhir J, Kind AJ, Campbell K. Viable Offspring Derived from Fetal and Adult Mammalian Cells. Cloning Stem Cells. 2007; 9, 3-7. DOI: 10.1089/clo.2006.0002.

19. Goto Y, Hirayama M, Takeda K, Tukamoto N, Sakata O, Kaeriyama H, et al. Effect of synchronization of donor cells in early G1-phase using shake-off method on developmental potential of somatic cell nuclear transfer embryos in cattle. J Anim Reprod Sci. 2013; 84, 592-599. DOI: 10.1111/asj.12047.

20. Johnson R, Van LB, Papaioannou V, Spiegelman B.A null mutation at the c-jun locus causes embryonic lethality and retarded cell growth in culture. Genes Develop. 1993; 7, 1309-1317. PMID: 8330736.

21. Boquest AC, Day BN, Prather RS. Flow cytometric cell cycle analysis of cultured porcine fetal fibroblast cells. J Biol Reprod. 1999; 60, 1013-1019. PMID: 10084979.

22. Gerger RP, Ribeiro ES, Forell F, Bertolini LR, Rodrigues JL, Ambrósio CE, et al. In vitro development of cloned bovine embryos produced by handmade cloning using somatic cells from distinct levels of cell culture confluence. Genet Molr Res. 2010; 9, 295-302. DOI: 10.4238/vo19-1gmr690.

23. Hall VJ, Stojkovic P, Stojkovic M. Using Therapeutic Cloning to Fight Human Disease: A Conundrum or Reality?. Stem Cells. 2006; 24, 1628-1637. DOI: 10.1634/stemcells.2005-0592.

24. Freshney IR. Culture of Animal Cells. 4th ed. New York: I. Wiley-Liss. 2000; 335-337. DOI: $10.1002 / 9780471747598$.

25. Vanselow J, Furbass R, Tiemann U. Cultured Bovine Trophoblast Cells Differentially Express Genes Encoding Key Steroid Synthesis Enzymes. Placenta. 2008; 29, 531-538. DOI:

10.1016/j.placenta.2008.03.004.

26. Taylor IW, Milthorpe BK. An evaluation of DNA fluorochromes, staining techniques, and analysis for flow cytometry. I. Unperturbed cell populations. J Histochem Cytochem. 1980; 28, 1224-1232. DOI: 10.1177/28.11.6159392.

27. Leibfried L, First NL. Characterization of bovine follicular oocytes and their ability to mature in vitro. J Anim Reprod Sci. 1979; 48, 76-86. DOI:10.2527/jas1979.48176x.

28. Furnus CC, De Mattos DG, Moses DF. Cumulus expansion during in vitro maturation of bovine oocytes: relationship with intracellular glutathione level and its role on subsequent embryo development. J Mol Reprod Develop. 1998; 51, 76-83. DOI: 10.1002/(SICI)1098-2795(199809)51:1<76::AID-MRD9>3.0.CO;2-T.

29. Stringfellow DA, Seidel SM. Manual of the International Embryo Transfer Society: a procedural guide and general information for the use of embryo transfer technology emphasizing sanitary procedures. Savoy Illionis: 3rd ed IETS. 1998; 172. OCLC: 191852799.

30. Akagi S, Matsukawa K, Takahashi S. Factors Affecting the Development of Somatic Cell Nuclear Transfer Embryos in Cattle. J Reprod Develop. 2014; 60, 329-335. PMCID: PMC4219988.

31. Gibbons J, Arat S, Rzucidlo J, Miyoshi K, Waltenburg R, Respess D, et al. Enhanced survivability of 
cloned calves derived from roscovitine-treated adult somatic cells. J Biol Reprod. 2002; 66, 895-900. PMID: 11906906.

32. Hashem MA, Dilip DP, Kang SK, Lee BC, Suk HW. Cell cycle analysis of in vitro cultured goral (Naemorhedus caudatus) adult skin fibroblasts. Cell Biol Int. 2006; 30, 698-703. DOI: 10.1016/j.cellbi.2006.04.008.

33. Goissis MD, Caetano HV, Marques MG, De Barros FR, Feitosa WB, Milazzotto MP, et al. Effects of serum deprivation and cycloheximide on cell cycle of low and high passage porcine fetal fibroblasts. J Reprod Domestic Anim. 2007; 42, 660-663. DOI: 10.1111/j.1439-0531.2006.00839.x.

34. Koo CH, Kwon HJ, Eorn J, Chagn J, Han HS, Jhonson M. Control of spin precession in a spin-injected field effect transistor. Science. 2009; 325, 1515-1518. DOI: 10.1126/science.1173667.

35. Kubota H, Nishizaki T, Harada K, Oga A, Ito H, Suzuki M, et al. Identification of recurrent chromosomal rearrangements and the unique relationship between low-level amplification and translocation in glioblastoma. Genes Chromosom Cancer. 2001; 31, 125-133. DOI: 10.1002/gcc.1126.

36. Liu H, Radisky DC, Wang F, Bissell MJ. Polarity and proliferation are controlled by distinct signaling pathways downstream of PI3-kinase in breast epithelial tumor cells. J Cell Biol. 2004; 164, 603-612. DOI: $10.1083 /$ jcb.200306090.

37. Hayes JD, Flanagan JU, Jowsey IR. Glutathione transferases. Annual Rev Pharm Tox. 2005; 45, 51-88. DOI: 10.1146/annurev.pharmtox.45.120403.095857.

38. Sun Y, Pollard S, Conti L, Toselli M, Biella G, Parkin G, et al. Long-term tripotent differentiation capacity of human neural stem (NS) cells in adherent culture. Mol Cell Neurosci. 2008; 38, 245-258. DOI: 10.1016/j.men.2008.02.014.

39. Jandt U, Platas O, Pörtner R, Zeng AP. Mammalian cell culture synchronization under physiological conditions and population dynamic simulation. Appl Microb Biotech. 2014; 98, 4311-4319. DOI: 10.1007/s00253-014-5553-6.

40. Jandt U, Platas O, Pörtner R, Zeng AP. Synchronized mammalian cell culture: Part II-population ensemble modeling and analysis for development of reproducible processes. J Biotech Progress. 2015; 31,175185. DOI: $10.1002 /$ btpr.2006.

41. Giraldo AM, Lynn JW, Godke RA, Bondioli KR. Proliferative characteristics and chromosomal stability of bovine donor cells for nuclear transfer. J Mol Reprod Develop. 2006; 73, 1230-1238. DOI: 10.1002/mrd.20558.

42. Opiela J, Samiec M, Bochenek M, Lipinski D, Romanek J, Wilczek P. DNA Aneuploidy in Porcine Bone Marrow-Derived Mesenchymal Stem Cells Undergoing Osteogenic and Adipogenic In Vitro Differentiation. J Cell Reprogram. 2013; 15,425-434. https://doi.org/10.1089/cell.2012.0099.

43. Im GS, Seo JS, Hwang IS, Kim DH, Kim SW, Yang BC, et al. Development and apoptosis of preimplantation porcine nuclear transfer embryos activated with different combination of chemicals. J Mol Reprod Develop. 2006; 73, 1094-1101. DOI: 10.1002/mrd.20455. 
44. Kharche S, Birade D. Parthenogenesis and activation of mammalian oocytes for in vitro embryo production: A review. Adv Biosci Biotech. 2013; 4,170-182. DOI: 10.4236/abb.2013.42025.

45. Bang JI, Jin JI, Ghanem N, Choi BH, Fakruzzaman M, Ha AN et al. Quality improvement of transgenic cloned bovine embryos using an aggregation method: Effects on cell number, cell ratio, embryo perimeter, mitochondrial distribution, and gene expression profile. Theriogenology. 2015; 84, 509-523. DOI: 10.1016/j.theriogenology.2015.04.008.

46. Moraes L, Moraes F, Moreira A. Efeito da cianogênese na incompatibilidade entre clones de copa de seringueira e o clone de painel IPA. PAB. 2002 37, 925-932. http://dx.doi.org/10.1590/S0100204X2002000700005.

47. Totey SM, Daliri M, Appa Rao KB, Pawshe CH, Taneja M, Chillar RS. Differential cleavage and developmental rates and their correlation with cell numbers and sex ratios in buffalo embryos generated in vitro. Theriogenology. 1996; 45, 521-533. PMID: 16727815.

48. Forell F, Feltrin C, Carboneiro Dos Santos L, Maciel da Costa U, Diniz Vieira A, Hölker, M, et al. Use of bovine oocytes as recipient cytoplasm in the production of embryos through nuclear transfer of interspecies somatic cells (NTSCi). Acta Sci Vet. 2008; 36, 141-147. ISSN 1678-0345 (Print) ISSN 1679-9216 (Online).

49. Almeida AB. Sistema biológico de aumento de taxa de prenhes. Embriões partenogenéticos podem ajudar o reconhecimento da gestação, São Paulo, BR. Universidade de São Paulo Tese. 2008; DOI 10.11606/T.10.2008.tde-28112008-085807.

50. Choresca HC, Koob OJ, Ohb HJ, Hongb SG, Gomez DK, Kim JH, et al. Different culture conditions used for arresting the $\mathrm{G} 0 / \mathrm{G} 1$ phase of the cell cycle in goldfish (Carassius auratus) caudal fin-derived fibroblasts. Cell Biol Int. 2009; 33, 65-70. DOI: 10.1016/j.cellbi.2008.09.015. 